\title{
Toward an understanding of human responses to environmental change in the Caspian-Black Sea-Mediterranean Corridors (IGCP 610 final report)
}

\author{
${ }^{1}$ Odessa I.I. Mechnikov National University, 2 Dvoryanskaya Str., Odessa 65082, Ukraine; *Corresponding author, E-mail:valyan@onu.edu.ua \\ ${ }^{2}$ Avalon Institute of Applied Science, 976 Elgin Avenue, Winnipeg MB R3E 1B4, Canada \\ ${ }^{3}$ Lomonosov Moscow State University, 1 Leninskiye Gory, Moscow, 119991, Russia
}

(Received: December 30, 2018; Revised accepted: August 28, 2019)

https://doi.org/10.18814/epiiugs/2019/019028

\section{Introduction}

The Caspian-Black Sea-Mediterranean Corridor ["CORRIDOR"] encompasses the Eurasian intercontinental basins of the Caspian, Black, Marmara, Aegean, and Eastern Mediterranean (Levantine) seas with their connecting straits and coasts. Periodic connection/isolation of the basins during the Quaternary predetermined their specific environmental conditions and particular hydrologic regimes, and thus, the area, and especially the Ponto-Caspian, represents a "natural laboratory" to study the responses of semi-isolated and isolated basins to climate changes. Being characterized by rich sedimentary, geomorphological, archaeological, paleoanthropological, and historical records, the "CORRIDOR" provides a superb opportunity to assess the influence of climate, sea-level change, and coastline migration on human development (e.g., Yanko, 1990; Anthony, 2007; Stanko, 2007; Smyntyna, 2007; Yanko-Hombach, 2007; Yanko-Hombach et al., 2011; Yanina, 2012; Yanko-Hombach et al., 2014; Yanko-Hombach and Kislov, 2018; Yanina et al., 2017) and foraminifera (Yanko, 1990; Yanko-Hombach, 2007). This, in turn, has enabled the correlation of major events in this region with those in the Mediterranean Sea and the World Ocean. It has also allowed a reconstruction of the time and direction of Caspian and Mediterranean intrusions into the Black Sea via the connecting straits (Yanko and Motnenko, 2012).

Despite over 150 years of intensive field studies and interpretative research, many aspects of the geological history as well as human responses to environmental changes in the "CORRIDOR" during the Quaternary remain disputed, and many questions remain unsolved. These difficulties have necessitated a multidisciplinary and integrated investigation performed by an international and framework of researchers toward a better understanding of environmental change and its impacts in the "CORRIDOR."

The main goal of the IGCP 610 Project is to provide cross-disciplinary and cross-regional correlation of geological, archaeological, environmental, and anthropological records in order to (a) explore interrelationships between environmental change and human adaptation during the Quaternary, (b) create a networking and capacity-build- ing structure to develop new interdisciplinary research initiatives, and (c) provide guidance to heritage professionals, policy makers, and the wider public on the relevance of studying the "CORRIDOR" for a deeper understanding of Eurasian history, environmental changes and their relevance, as well as past and future impacts on humans.

To achieve the main goal and objectives, the Project has a triple focus: (1) geological history, (2) paleoenvironmental change (climate, sea level, coastline migration), and (3) human response (migration, subsistence strategy, physical and cultural adaptation, etc.) to environmental changes. Six dimensions of evidence are explored by integrating existing data and hypothesis testing: 1 . The geological dimension examines the sedimentary record of vertical sea-level fluctuations and lateral coastline change. 2. The paleoenvironmental dimension integrates paleontological, palynological, and sedimentological records to reconstruct paleolandscapes. 3. The archaeological dimension investigates cultural remains. 4. The paleoanthropological dimension studies responses of different Homo species to environmental change. 5. The mathematical dimension provides GIS-aided mathematical modeling of climate, sea-level change, and human dispersal linked to environmental change. 6 . The geo-information dimension will try to grasp the "big picture" of geoarchaeological events throughout the Quaternary. Attention is constantly given to synthesizing the wealth of literature published in local languages, stored in archives, and largely unknown in the West.

\section{Main Achievements of IGCP 610 during 2013-2018}

The Project commenced on 1 April 2013. Since that time, it has served as a focal point for correlation of scientific data obtained by research projects dealing with environmental change and human response in a variety of settings within the CORRIDOR during the Quaternary. In general, six years of IGCP 610 activity have been carried out in strict agreement with the Working Plan [http://www.avalon-institute.org/ IGCP610/work_plan.php].

Today, the network of IGCP 610 includes about 260 scientists from 22 countries: Azerbaijan, Belgium, Bulgaria, Canada, Georgia, Germany, China, Greece, France, Israel, Italy, Kazakhstan, Latvia, Roma- 
nia, Russia, The Netherlands, Switzerland, Turkey, Turkmenistan, UK, Ukraine, and the USA. The Project provides a friendly platform for participants to communicate their own research results, to bring together global experts and research facilities to reach the main goal.

\section{Plenary Conferences, Field Work, Workshops, and Train- ing Schools of IGCP 610}

Six IGCP 610 Plenary Conferences and Field Trips were carried out in the following regions: 2013 - Western Georgia; 2014 - Azerbaijan; 2015 - Russia (Northern Caspian); 2016 - Eastern Georgia (Inner Kartli and Kakheti regions); 2017 - Palermo, Italy; 2018-Antalya, Turkey (Fig. 1).

The Field Trips carried out after the Plenary Sessions enabled participants, under the guidance of local experts, to visit many relevant sites in the "CORRIDOR" that would otherwise have been very difficult to see, and discuss important scientific issues about these sites with colleagues (the Field Trip Guides can be downloaded from http:/ /www.avalon-institute.org/IGCP610/meeting_past.php). During the Field Trips participants studied the reference Quaternary type sections, including the Pliocene-Pleistocene boundary. Obtained data were treated in related laboratories over the world.

The First Plenary Conference and Field Trip of IGCP 610 was organized by the Institute of Earth Sciences, Ilia State University, and the Avalon Institute of Applied Science, Winnipeg, Canada, and hosted by Ilia State University, on 12-19 October 2013, in Tbilisi, Georgia (Yanko-Hombach, 2016). One hundred and fifty-one scientists from
19 countries contributed to the conference; $66 \%$ of them were from developing countries. Their peer-reviewed contributions are assembled in a 182-page Conference Proceedings volume (Gilbert and Yanko-Hombach, 2013).

Four days were devoted to the Field Trips (by bus) and were led by prominent Georgian geologists and archaeologists (Okrostsvaridze et al., 2013).

The Second Plenary Conference and Field Trip of IGCP 610 was organized by the Institute of Geology and Geophysics of the Azerbaijan National Academy of Sciences and the Avalon Institute of Applied Science, Winnipeg, Canada, and hosted by the former on 12-20 October 2014, in Baku, Azerbaijan. One hundred and twenty-four scientists from 18 countries contributed to the conference; $71 \%$ of them were from developing countries. Their peer-reviewed contributions are assembled in a 186-page Conference Proceedings volume (Gilbert and YankoHombach, 2014).

The meeting was focused on the whole spectrum of Quaternary geological sequences exposed in the terraces and ridges of the Caspian region.

Five days were devoted to the Field Trips (by bus) and were led by prominent Azerbaijani geologists and archaeologists. They were focused on the Apsheronian stage sediments, the classic stratotype of the Mountain of Bakinian stage, examples of the rapid Caspian Sea level changes in the Pleistocene successions, Azerbaijan mud volcanoes, Western Azerbaijan and the Greater Caucasus continuous outcrop of Quaternary continental sediments of the Ajinour, the reference outcrop of the marine Bakinian sediments at Bozdag, as well as archaeo-

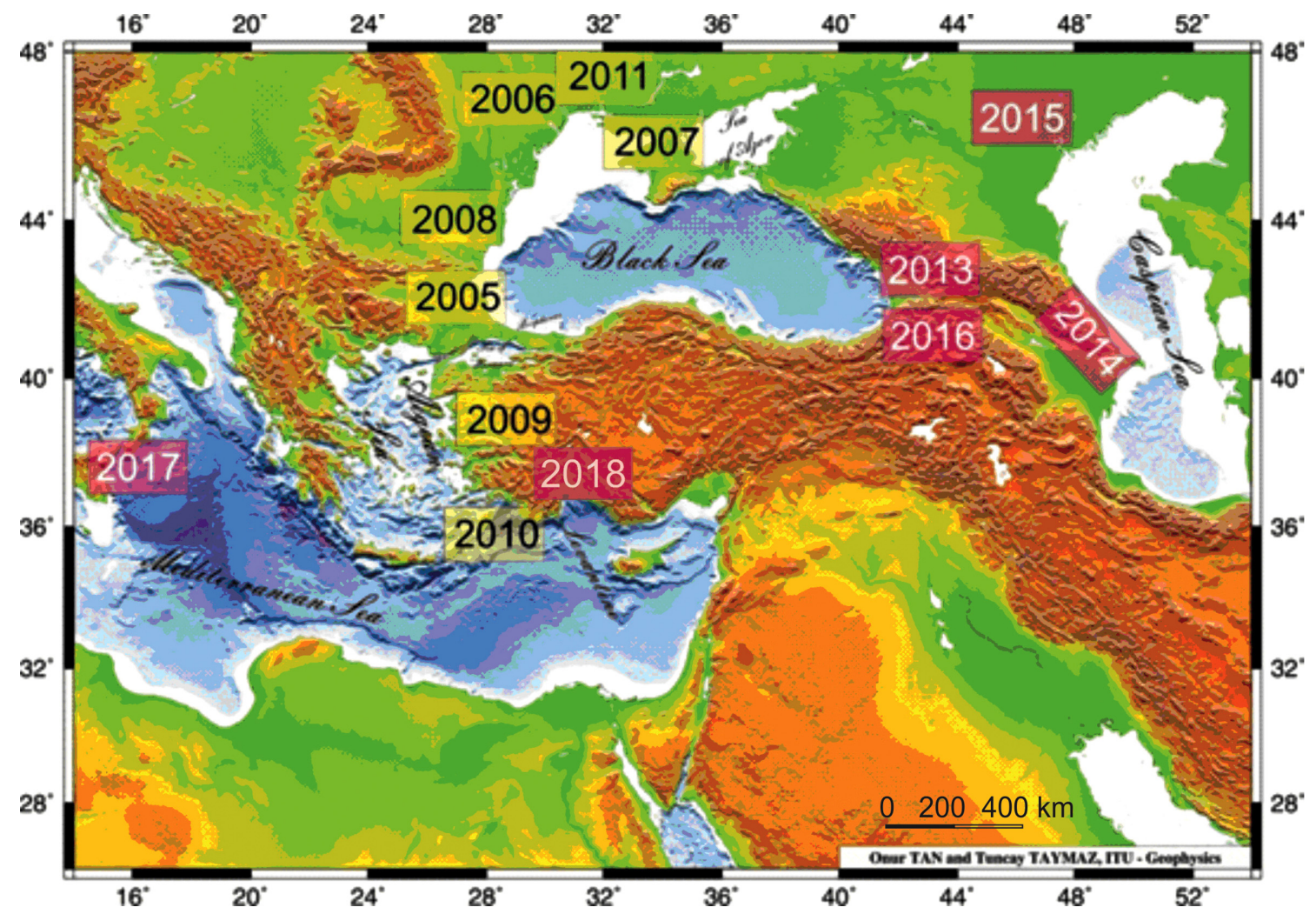

Figure 1. The Caspian-Black Sea-Mediterranean "CORRIDOR”: in yellow are the locations of IGCP 521-INQUA 501 meeting and field trip sites (2005-2011); in other colors are sites studied by the ongoing IGCP 601 Project: 2013 - Tbilisi, Western Georgia; 2014 - Baku, Azerbaijan; 2015 - Astrakhan' (Volga Delta), Russia; 2016 - Tbilisi, Eastern Georgia; 2017 - Palermo, Italy; 2018 - Antalya, Turkey. 


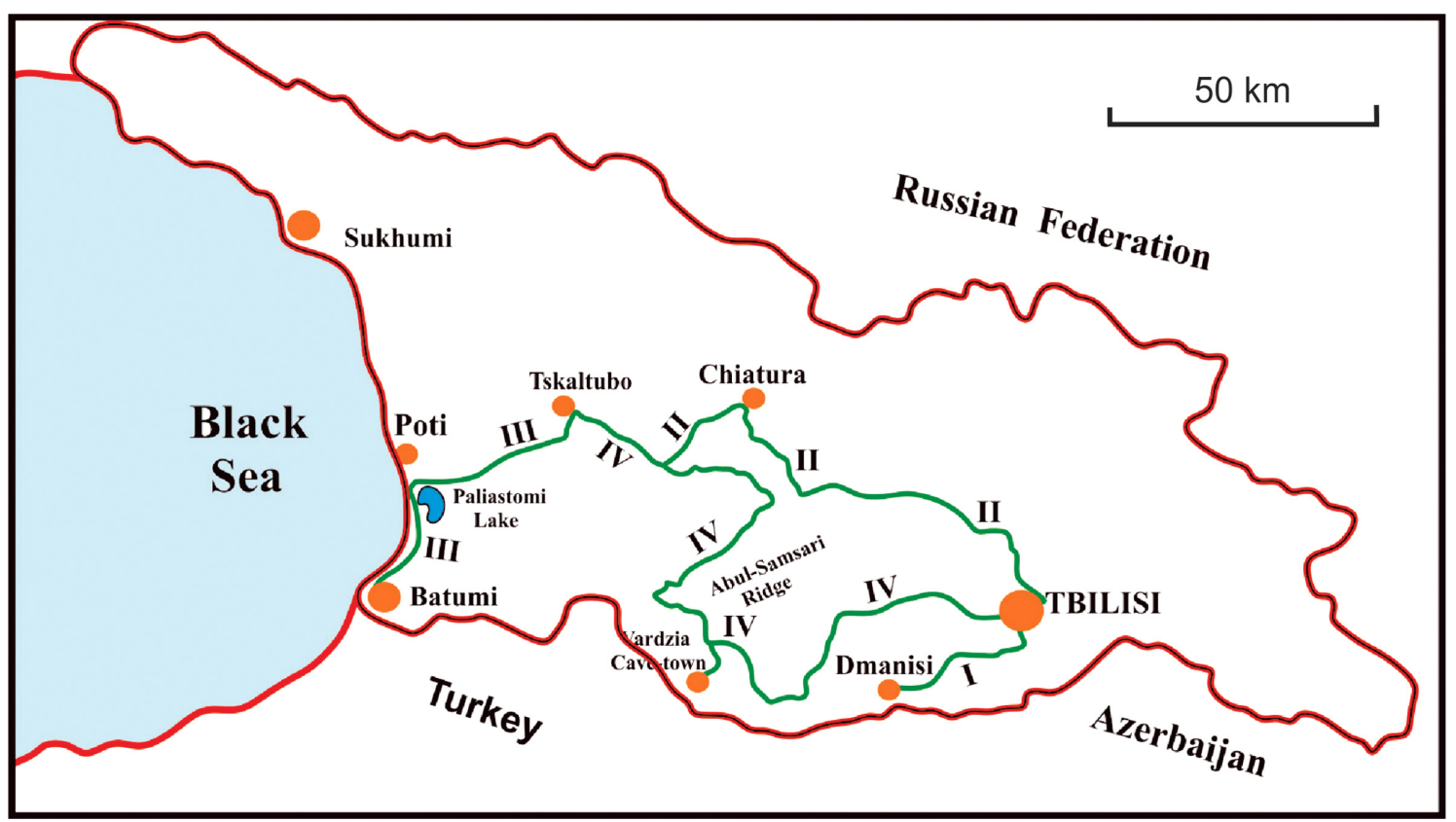

Figure 2. Map of Georgia with geological and archaeological sites visited during the Field Trips of IGCP610 in 2013. Field Trip I: Mtskheta, Chiatura Paleolithic sites, Sataplia dinosaur footprints, and cave state reserve. Field Trip II: Mtskheta, Chiatura Paleolithic sites, Sataplia dinosaur footprints, and cave state reserve. Field Trip III: Paliastomi Lake, Tsvermagala Chaudian Black Sea Terrace, Batumi seashore. Field Trip IV: Dzirula massif, Borjomi, Vardzia Cave Town and Quaternary Abul-Samsari volcanic ridge (Okrostsvaridze et al., 2013).

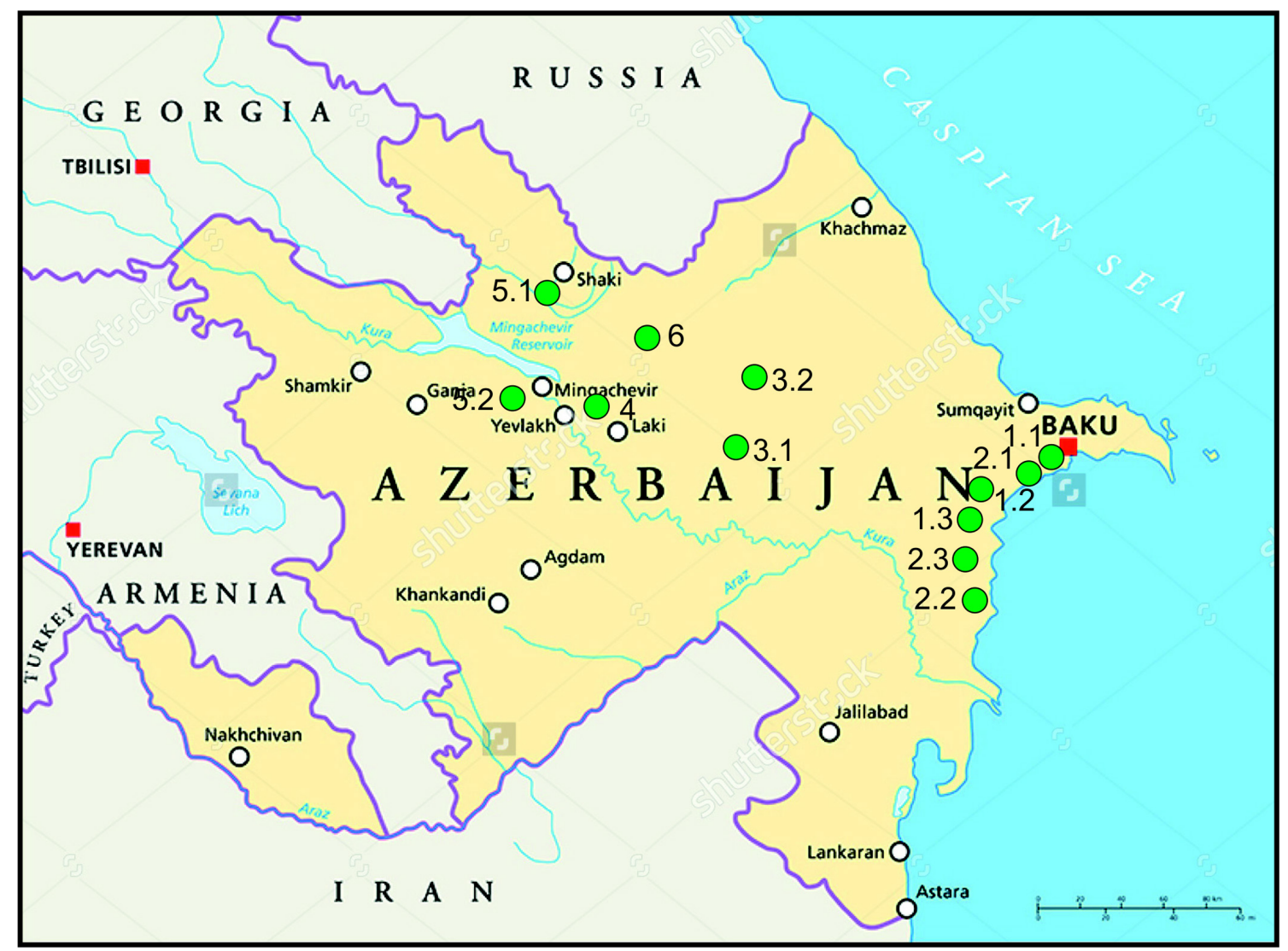

Figure 3. Map of Azerbaijan with geological and archaeological sites visited during the Field Trips of IGCP 610 in 2014 (Aliyeva and Kangarli, 2014).

logical sites of Gobustan, Gabala, and historical sites of Baku and Lagich (Fig. 3; Aliyeva and Kangarli, 2014).
The Third Plenary Conference and Field Trip of IGCP 610 was organized by the Astrakhan Museum-Reserve, M.V. Lomonosov Mos- 
cow State University, Astrakhan State University, Russia, and the Avalon Institute of Applied Science, and hosted by the former. One hundred and seven scientists from 14 countries contributed to the conference; $77 \%$ of them were from developing countries. Their peerreviewed contributions are assembled in a 220-page Conference Proceedings volume (Gilbert et al., 2015).

Five days were devoted to the Field Trips (by bus and boat) and were led by prominent Russian geologists and archaeologists. The Field Trips were focused on the spectrum of Quaternary geological sequences exposed within sections of the Lower Volga area (Cherniy Yar - Nizhnee
Zaimische, Kopanovka, Lenino, Seroglazka). The conference participants were able to see deposits of the Bakinian, Early Khazarian, Late Khazarian, Khvalynian, and Novocaspian transgressions, and the continental sediments separating them: Singilsky, Chernoiarsky, and Atel. They also observed the Baer knolls, a unique natural formation that has no analogues in the world (Fig. 4; Yanina et al., 2015).

The Fourth Plenary Meeting and Field Trip of IGCP 610 was organized by the Georgian National Academy of Sciences, Ilia State University, Georgia, and Avalon Institute of Applied Science, and hosted by the by the former. The Meeting and Field Trips were held in Tbilisi

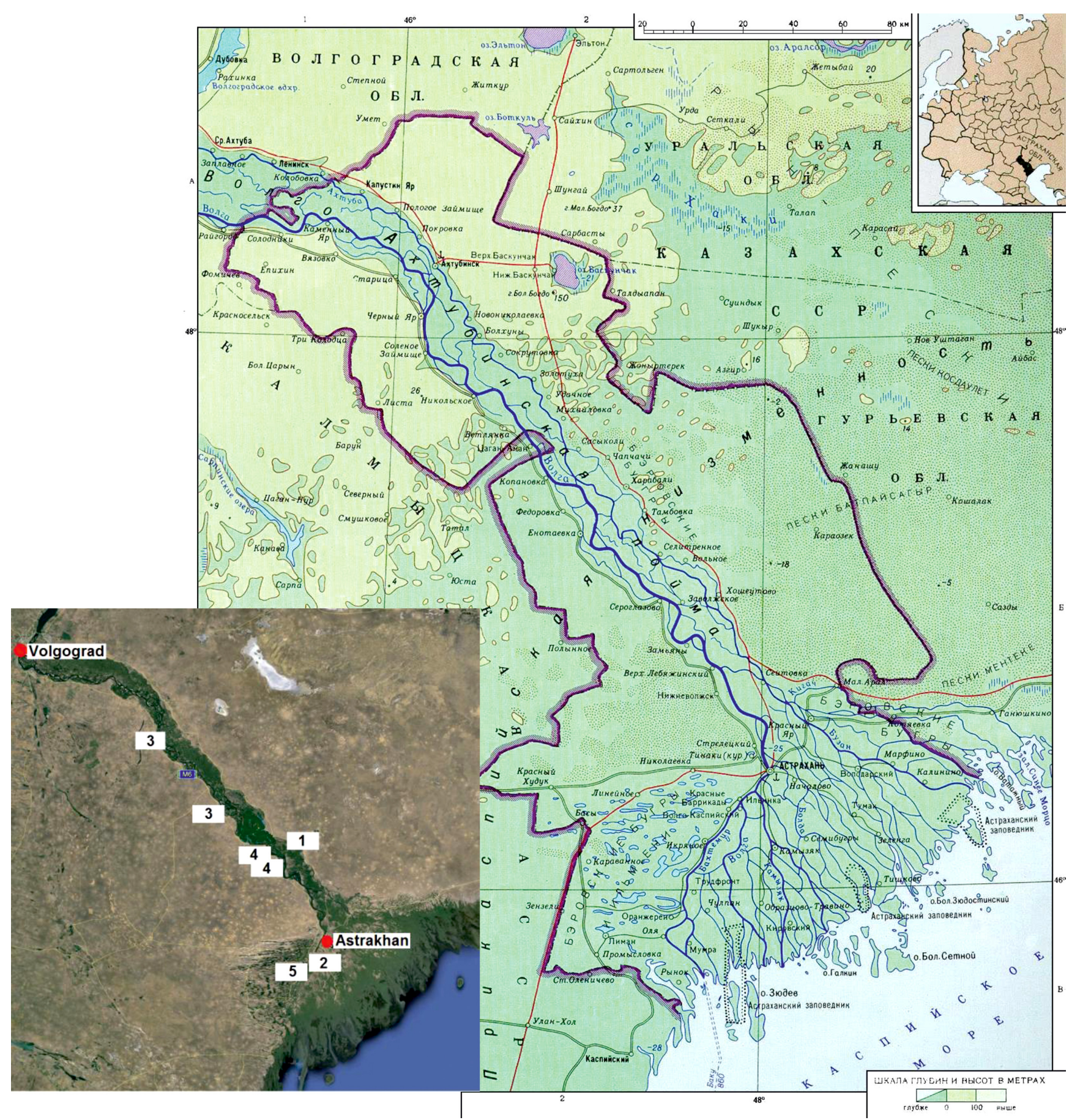

Figure 4. Map of the Lower Volga region with geological and archaeological sites visited during the Field Trips of IGCP 610 in 2015 (Yanina et al., 2015). 


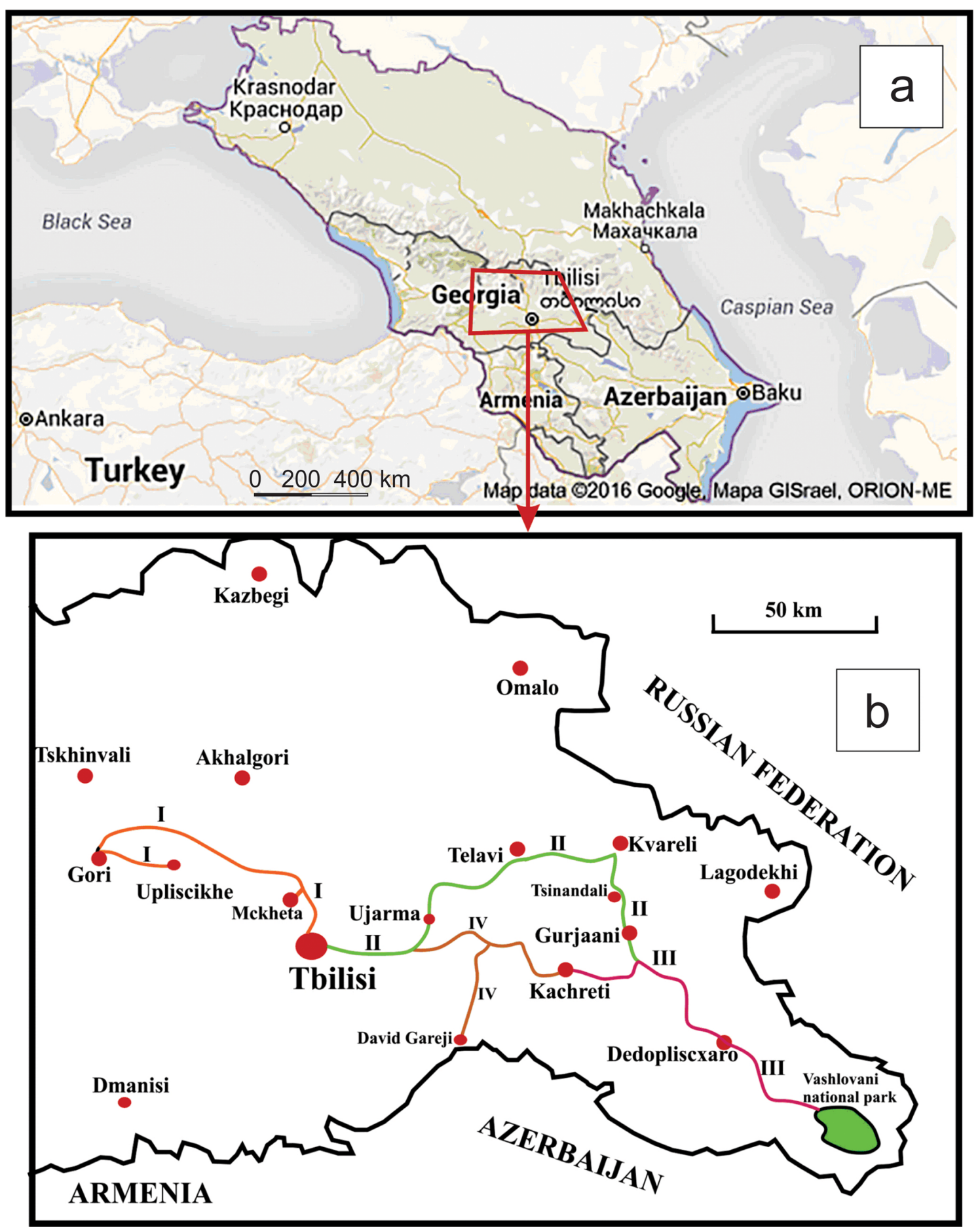

Figure 5. Map of the Eastern Georgia region with geological and archaeological sites visited during the Field Trips of IGCP 610 in 2016 (Gamkrelidze et al., 2016).

and Eastern Georgia, respectively (Fig. 5; Gamkrelidze et al., 2016).

The meeting focused on the pre-Pleistocene and Pleistocene geological history of the Eastern Paratethys remnants within Eastern Georgia. This subject is very important in achieving a better understanding of a possible mechanism of separation of the Eastern Paratethys into the individual seas leading to formation of the Black and Caspian Seas.

Four days were devoted to the Field Trips (by bus). The Field Trips were focused on large sequences of freshwater-continental sediments of the Miocene, Pliocene, and post-Pliocene that fill all major depressions of the Kartli and Kakheti depressions as well as s variety of uplift regimes during the Quaternary. They we investigated by conference participants in the Mtskheta-Uplistsikhe, Kakheti regions, and Mount Gareja areas while a good cross-section of marine Akchagylian sediments was observed on the left bank of the Iori River, at the foot of Qvabebi mount.

The 218-page Proceedings of the Fourth Plenary Meeting (Gilbert 


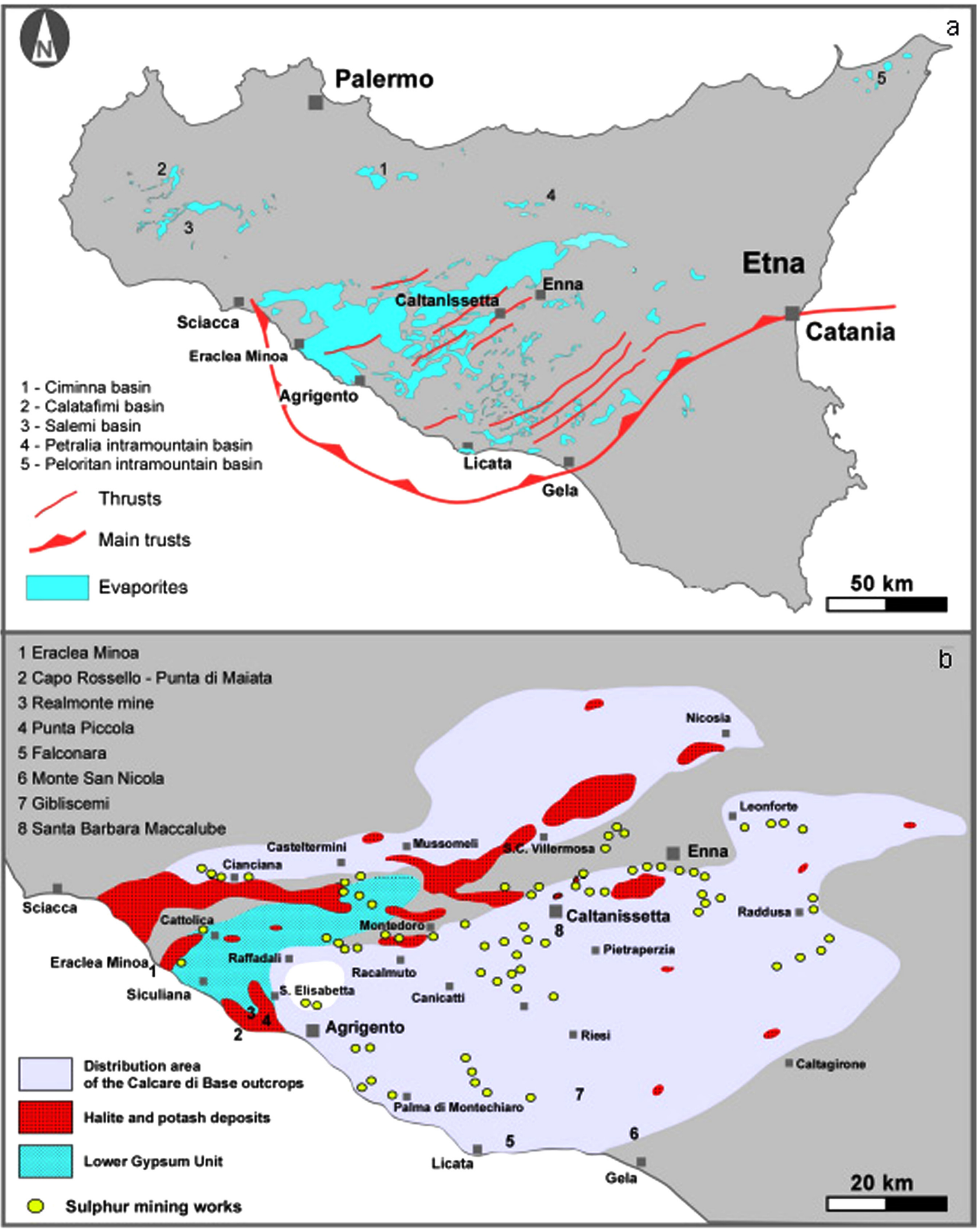

Figure 6. Map of the Southern Sicily with geological and archaeological sites visited during the Field Trips of IGCP 610 in 2017 (Caruso et al., 2017).

and Yanko-Hombach, 2016) contain contributions from 107 scientists from two continents and 17 countries; $89 \%$ of the contributors were from developing countries. About $50 \%$ of the participants were female. This particular conference was characterized by an especially high number of young scientists and students.

A special volume of Quaternary International "IGCP 610 III" col- 
lected about 15 articles presented at the meeting, and was published in 2018.

The Fifth Plenary Meeting and Field Trip of IGCP 610 and the First Meeting of POCAS was organized by the University of Palermo, and the Avalon Institute of Applied Science, Canada, and hosted by the University of Palermo. The Meeting and Field Trip were held in Palermo and southern Italy (Sicily and Calabria), respectively (Fig. 6; Caruso et al., 2017).

The movie and photo gallery of these Field Trips can be seen at http://www.avalon institute.org/IGCP610/public_outreach.php. The Conference and Field Trips focused on the Plio/Pleistocene geological history of the central Mediterranean of southern Italy (Sicily and Calabria). This subject is very important in achieving a better understanding of climate evolution during the Plio/Quaternary.

The 239-page Proceedings of the Conference (Gilbert and YankoHombach, 2017) contain contributions from 109 scientists from 14 countries; $61 \%$ of the contributors are from developing countries. About $50 \%$ of participants were female. The conference was characterized by a substantial number of young scientists and students.

Five days were devoted to the Field Trips (by bus) and were led by prominent Italian geologists and archaeologists. The 49-page Field Trip Guide describes the Messinian-Zanclean GSSP, the Capo Rossello area with one of the most beautiful and complete sedimentary successions of the upper Messinian to lower Pleistocene, and is particularly suitable for the study of the Plio/Pleistocene boundary, the Punta di Maiata natural cliff where calcareous and marly limestones of the Trubi Fm outcrop, the Punta Piccola-Zanclean/Piacenzian GSSP, the Gelasian GSSP, the almond field of Monte San Nicola with the local succession: cyclic sedimentation and sapropel clusters, the Nicola bed: a close encounter with the Gelasian GSSP, the Gibliscemi section, the Agrigento Valle dei Templithat is an archaeological area of Sicily characterized by its exceptional state of conservation and a series of important Doric temples of the Greek period (Caruso et al., 2017).

The Sixth Plenary Meeting and Field Trip of IGCP 610 and the Second Meeting of POCAS was held on 14-21, 2018 in Antalya, Turkey. It focused on the late Miocene-Plio/Pleistocene geological history of the eastern Mediterranean of southern Turkey along the central Taurid Mountains. This subject is very important in shedding light and achieving a better understanding of tectonic-climatic interactions during the Plio/Quaternary period in this region (Fig. 7).

The 218-page Proceedings of the meeting (Gilbert and Yanko-Hombach, 2018) and Field Trip of IGCP 610 and INQUA IFG POCAS, Antalya, Turkey, contain contributions from 86 scientists from two continents and 15 countries; $86 \%$ of the contributors were from developing countries. About $50 \%$ of participants were female. The conference was characterized by a relatively high number of young scientists and students.

The Conference enabled those in attendance (1) to discuss the actual status of both projects and progress made by participants, and (2) to lay out a strategy for future collaboration.

Four days were devoted to the Field Trips (by bus and boat). The Field Trips were focused on the Upper Miocene-Pliocene deposits of the Aksu (Antalya) Basin with the aim of showing the units and geological evolution of the Aksu Basin in this tectonically active region; the Kocain Cave and tufa sediments; the ancient Roman site Sagalossos, and the sunken Roman cities of Simena \& Teimussa, Kekova Bay

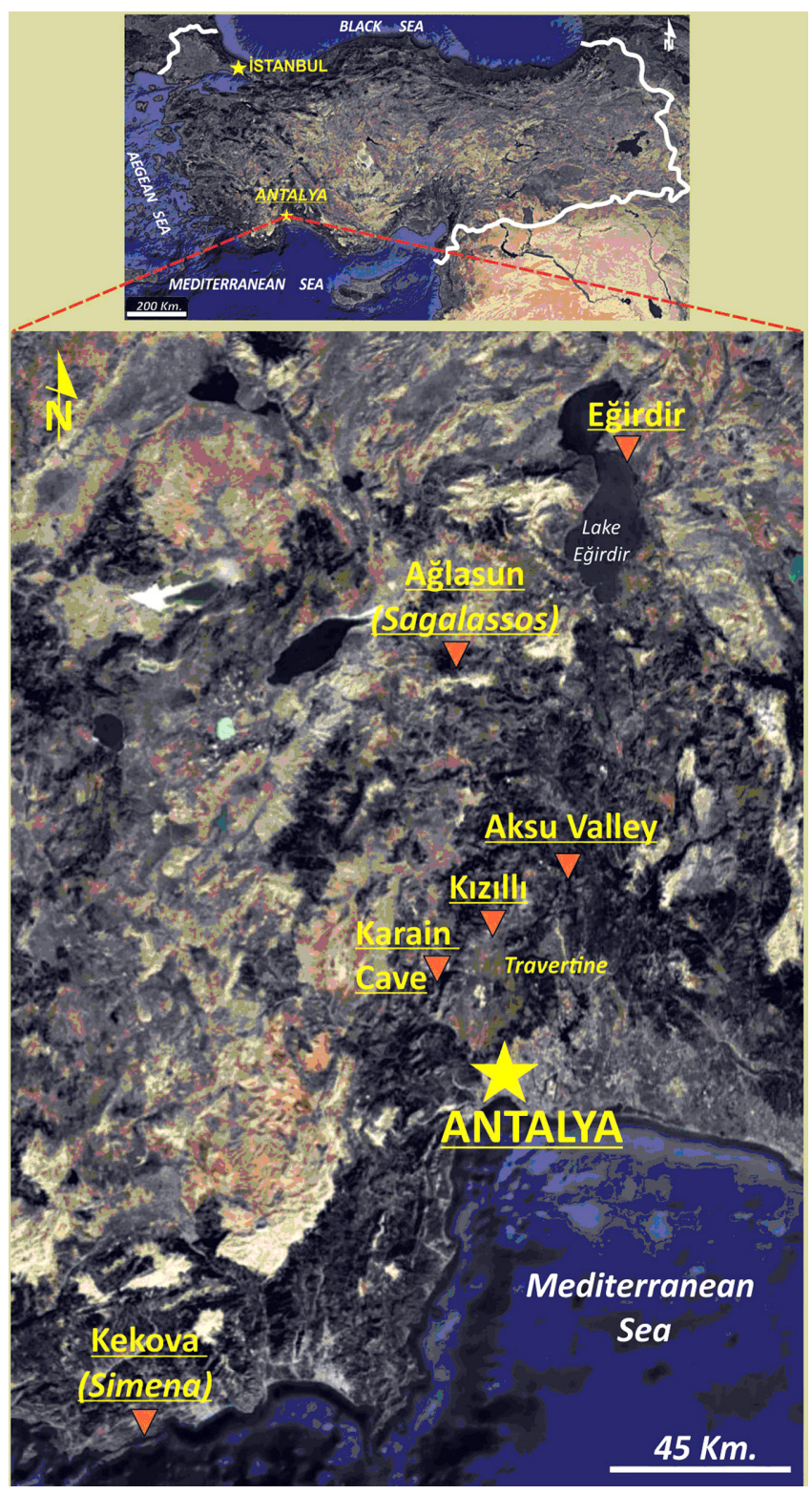

Figure 7. Field trip locations visited during the IGCP-INQUA POCAS meeting in 2018 (Koral et al., 2018).

(visited by boat) (Koral et al., 2018).

Overall, the Meetings and Field Trips provided an excellent opportunity for international discussion of different methods and interpretations used to analyze the history of a huge geographical area from the Caspian to the Mediterranean seas over the full duration of the Quaternary.

In addition to the conference and field trips, the IGCP 610 carried out field work in the Caspian Sea region (Supervisor T. Yanina), the Eastern Manych valley (Supervisor R. Kurbanov); in the Sea of Azov region (Supervisor T. Yanina), the Black Sea region (supervisor V. Yanko-Hombach); and in the Mediterranean Region (Supervisors H. Öniz and A. Frumkin).

Workshops were conducted in Sozopol (Bulgaria, September 2013), Kirklareli (Turkey, September 2014), Ahtopol (Bulgaria, December 2014), Moscow (Russia, April, and November 2015); all of them were 
devoted to stratigraphy, paleogeography, and geochronology of the "CORRIDOR".

Training Schools were carried out in summer (Kalmykiya, May 2014; the Danube Delta on-board the floating laboratory boat "Halmyris," Romania, 2013, 2014, 2015, 2016) and winter (Youth Expedition-Field School in the Manych depression, 2016, 2017). In addition, a School-Seminar for young researchers "Methods of deltaic systems study in the South of Russia" was held at the Faculty of Geography of Moscow State University in March 2017, while the international youth School-Conference "Where East meets West: Pontocaspia, the historical dimension of the evolution of a unique biodiversity" took place in Azov, Astrakhan (Russia, 2017).

\section{Main Scientific Results}

The project established a series of new data, such as: (1) local stratigraphic and geochronological scales assembled into a regional one with a purpose of correlating the major geological and environmental events in human prehistory and history with global environmental changes (Yanina et al., 2018; Yanko-Hombach, 2018); (2) chronostratigraphic correlation of the Ponto-Caspian and Mediterranean basins for the reconstruction of water exchange and the first peopling of Europe (Chepalyga, 2018); (3) dinoflagellate marker species of the relic Paratethyan seas: Pannonian to Caspian basins (Mudie et al., 2018); (4) the southern Levant caves as window to out of Africa hominin migration during Quaternary (Frumkin et al., 2018); (5) Eastern Paratethys - Mediterranean connections during the Neogene and Quaternary (Popov et al., 2018); (6) Adjustment theory in the study of human responses to global climate change in the Northwestern Black Sea region at the Pleistocene-Holocene boundary (Smyntyna, 2017); (7) a set of regional paleogeographic and geological maps (Popov et al., 2018); (8) a model for the processes of Caspian-Mediterranean corridor formation and Paratethys Sea-Lake degradation as well as a model for the filling of the Black Sea basin by Mediterranean salt water during the Holocene (Esin et al., 2015).

The project also (9) established the Reference List of main publications on Project subjects; a majority of which are published in Russian, and their titles required transliteration and translation into English, (10) collected data set on chronometry in the "CORRIDORS"; (11) assembled a reference collection of Ponto-Caspian foraminifera (supplemented by SEM images) and mollusks; (12) developed a method for search and discovery of submerged archaeological sites (e.g., Öniz and Dönmez, 2018; Kadurin et al., 2019); (13) reconstructed water exchange and faunal migrations during the Quaternary (e.g., Yanko et al., 1990; Yanko-Hombach, 2018; Figs. 8, 9); (14) established interactions between two different realms in the Marmara Gateway (Büyükmeriç et al., 2016, 2018); (15) determined Eastern Paratethys Mediterranean connections during the Neogene and Quaternary; and (16) formulated the Ponto-Caspian biostratigraphy, sea level, and salinity reconstructions using mollusks and benthic foraminifera as the main tool (Figs. 8, 9).

The major milestones during the full project duration (2013-2018) can be seen in the Table 1.

Ponto-Caspian geologic history has been reconstructed using a multidisciplinary approach to the study of Quaternary deposits in the
Caspian-Manych-Black Sea Corridors; this approach comprised analysis of both natural outcrops and cores by complex methods that included facies-lithological, paleopedological, malacofaunistic, micropaleonological, and palynological analyses supplemented by isotopic, radiocarbon, and optical luminescent dating. Results permitted paleogeographic events in both basins to be correlated and reconstructed (Figs. 8, 9).

\section{Social Benefits}

The Project has enjoyed success implementing cultural heritage projects, open-air site museums, training centers in schools with the possibility of conducting experimental research, working together with local Governmental and Non-Governmental Organizations across the Caspian-Black Sea-Mediterranean Corridors that we study as a single geographic unit, bypassing linguistic and political boundaries, and thus encouraging East-West dialogue, cooperation, and integration of researchers from different countries into the international R\&D community; enhancing our understanding of the links between environmental change and human adaptation, contributing to an improvement in human living conditions (especially for those at risk from coastal flooding), and promoting the wise use of the Earth as a human habitat; and preserving human heritage by addressing and clarifying existing archaeological, ethnological, and paleoanthropological questions concerning the evolution of human subsistence strategies, social and ideological spheres in the light of environmental change, and human physical and cultural adaptation theory.

\section{Educational, Training and Capacity Building Activities}

In general, IGCP 610 and related activities promoted a multidisciplinary approach in paleoenvironmental studies that encourages students in geology and geography to take archaeological courses and vice versa, thus stimulating teachers of the universities participating in IGCP 610 to modify their curricula and CVs; enhanced the direct contacts between western and eastern youth, creating the background for better understanding of modern priorities in the developing world of science and humanities; exposed the younger generation in developing countries to new analytical techniques and state-of-the-art data interpretation; taught the public about environmental evolution during the last climatic cycle and possible consequences of GCC anticipated to take full effect in this century; provided consultation on stratigraphy, paleogeography, palynology, macro- and microfauna to interested parties from Ukraine, Russia, Azerbaijan, Turkey, Iran, and Georgia.

\section{Activities Planned}

Efforts are ongoing to maximize IGCP 610 exposure via diffusion of results in key international journals and updates of our web pages to ensure wide accessibility and increased interactive potential for project participants, the scientific community at large, relevant agencies, and the public; to consolidate scientific achievements as a basis for developing future strategies; to continue to augment the funding 


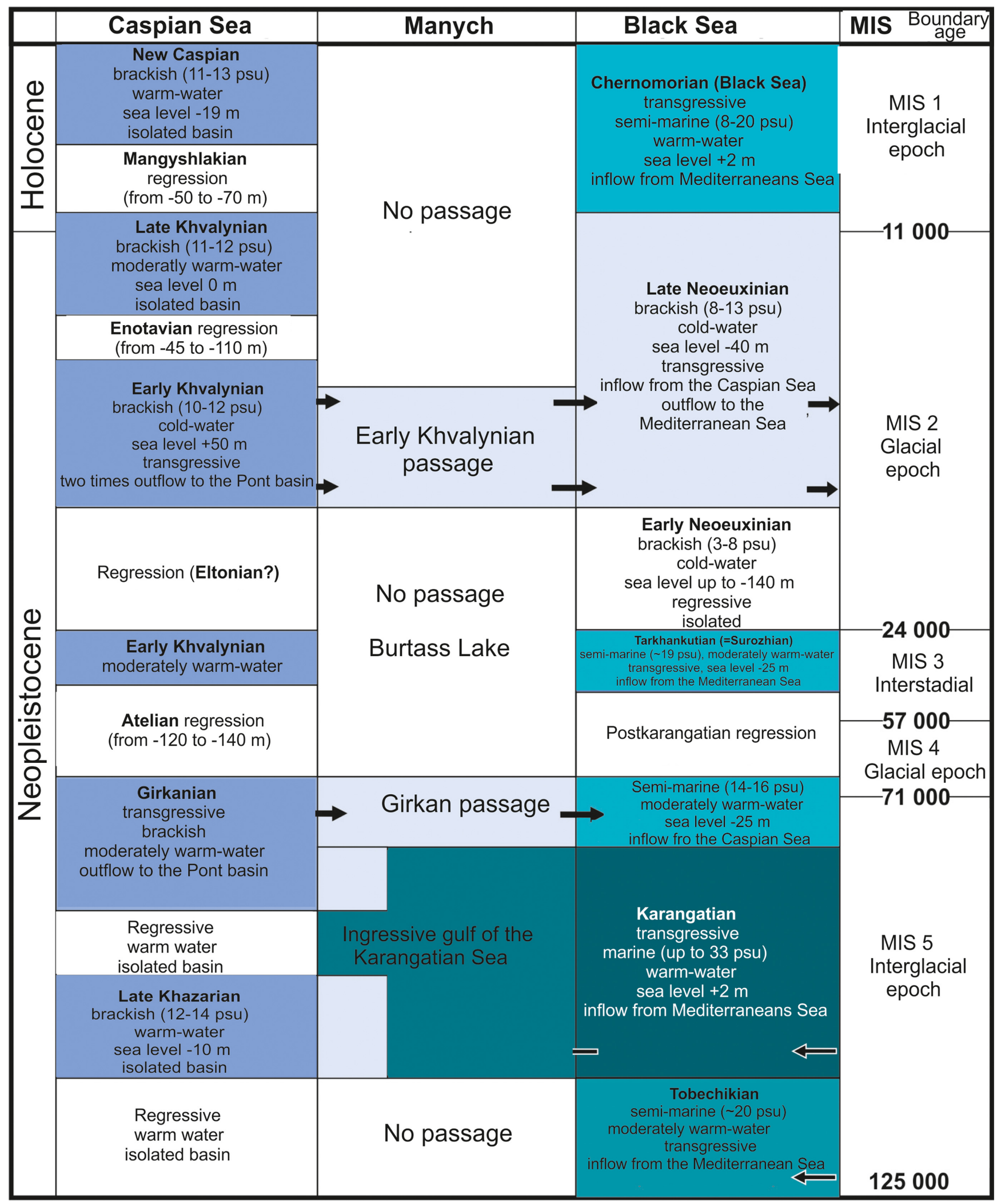

Figure 8. Scheme of the paleogeographical events in the Ponto-Caspian region during the Late Pleistocene and Holocene. Colours reflect the salinity of basins. Arrows point the outflow and the inflow of waters and migration of mollusks and forainifera between adjacent basins (modified after Yanina, 2014).

base with upcoming and submitted research proposals through various funding agencies; to publish the next special volume of Quater- nary International "IGCP 610 IV" devoted to the achievements of IGCP 610. 

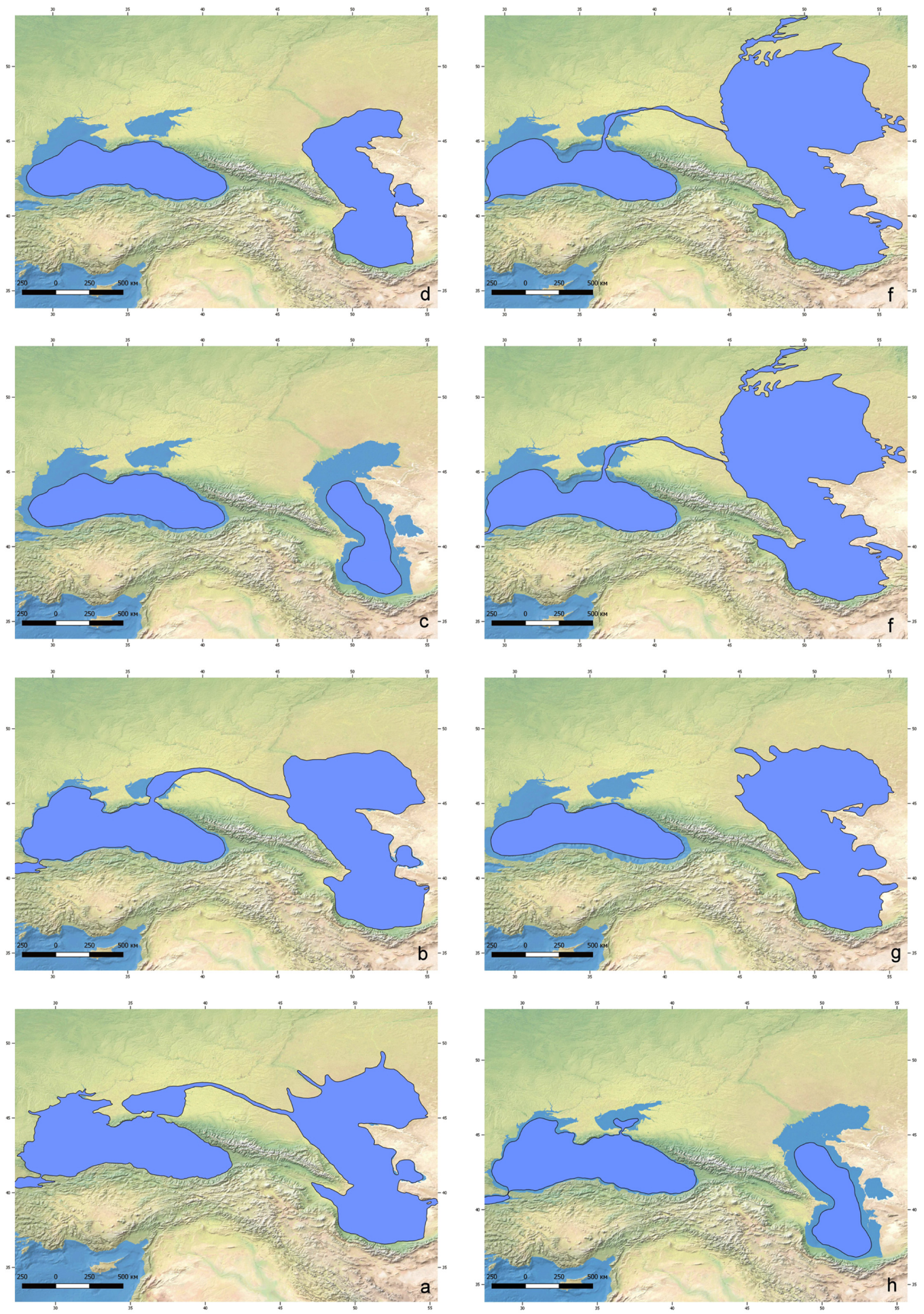

Figure 9. Paleoeconstructions of the Ponto-Caspian basins during the Late Pleistocene and Holocene under GCC: a - Interglacial (MIS 5, Mikulino interglacial on the Eastern European Plain): Karangatian regression of the Pont (with ingression into the Manych valley) and the Late Khazarian transgression of the Caspian (isolated basin); b - Transition from Interglacial (MIS 5) to Glacial (MIS 4): beginning of the Karangatian transgression of the Pont and Girkanian transgression of the Caspian, Girkanian passage in the Manych Valley; c-Early Glacial (MIS 4, Early Valdai Glaciation on the Eastern European Plain), Glacial maximum: Post-Karangatian regression of the Pont and Atelian regression of the Caspian; d-Interstadial warming (MIS 3, Bryansk Interstadial on the Eastern European Plain), Glacial degradation: Tarkhankutian (Surozhian) basin of the Pont and beginning of the Early Khvalynian transgression of the Caspian; $e$ - Late Glacial (MIS 2, Late Valdai Glaciation on the Eastern European Plain), Glacial maximum: the Early Neoeuxinian regression of the Pont and regression (Eltonian?) of the Early Khvalynian basin; $f$-Degradation of Glaciation (MIS 2): the Late Neoeuxinian transgression of the Pont and maximum of the Early Khvalynian transgression of the Caspian; - Glacial degradation (MIS 2) and beginning of post-Glacial (MIS 1): the Late Neoeuxinian transgression of the Pont and Late Khvalynian transgression of the Caspian; $h$ - Beginning of the Interglacial of the Holocene (MIS 1): beginning of the Chernorean (Black Sea) transgression of the Pont and the Mangyshlakian regression of the Caspian (modified after Yanina, 2014). 


\begin{tabular}{|c|c|c|}
\hline No & Milestone & Target date month, year \\
\hline M1 & Establishing the Reference List of main publications on Project subjects & $12 / 2014$ \\
\hline M3 & $\begin{array}{l}\text { Elaboration of the model for the filling of the Black Sea basin by Mediterranean salt water during the Holocene } \\
\text { (Esin et al., 2015) }\end{array}$ & $12 / 2015$ \\
\hline M2 & Establishing the data set on the Quaternary chronometry of the "CORRIDORS" & $12 / 2016$ \\
\hline M4 & $\begin{array}{l}\text { Elaboration of the model for the evolutionary mechanisms of the Paratethys Sea and its separation into the } \\
\text { Black Sea and Caspian Sea (Esin et al., 2018) }\end{array}$ & $12 / 2016$ \\
\hline M5 & $\begin{array}{l}\text { Assembling the Reference Collection of Ponto-Caspian foraminifera (supplemented by SEM images) and } \\
\text { mollusks }\end{array}$ & $12 / 2017$ \\
\hline M8 & $\begin{array}{l}\text { Establishing the regional stratigraphic and geochronological scales (Yanina et al., 2018; Yanko-Hombach, } \\
\text { 2018) }\end{array}$ & $10 / 2018$ \\
\hline M7 & $\begin{array}{l}\text { Correlation of the Ponto-Caspian and Mediterranean water exchange with the first peopling in Europe } \\
\text { (Chepalyga, 2018) }\end{array}$ & $08 / 2018$ \\
\hline M9 & $\begin{array}{l}\text { Reconstruction of the Eastern Paratethys - Mediterranean connections during the Neogene and Quaternary } \\
\text { (Popov et al., 2018) }\end{array}$ & $10 / 2018$ \\
\hline
\end{tabular}

\section{Acknowledgements}

This is a contribution of the IGCP-610 project of the IUGS and UNESCO.

\section{References}

Aliyeva, E., and Kangarli, T., 2014, Field Trip Guide of IGCP 610 Second Plenary Conference and Field Trip, 2014, Baku, 34 p.

Anthony, D. W. 2007. Pontic-Caspian Mesolithic and Early Neolithic societies at the time of the Black Sea flood: a small audience and small effects. In: Yanko-Hombach, V., Gilbert, A. S., Panin, N., and Dolukhanov, P. (Eds.) The Black Sea Flood Question: Changes in Coastline, Climate and Human Settlement. Dordrecht, Springer, pp. 345-370.

Büyükmeriç, Y., 2016, Postglacial floodings of the Marmara Sea: molluscs and sediments tell the story. Geo-Marine Letters, v. 36, pp. 307-321.

Büyükmeriç, Y., Alçiçek, H., and Alçiçek, M.C., 2018, Interactions between two different realms in the Marmara Gateway: an overview on Quaternary stratigraphy with new findings (NW Turkey). Proceedings of IGCP 610 and INQUA IFG POCAS Joint Plenary Conference and Field Trip, 2018, Antalya, pp. 44-45.

Caruso, A., Capraro, L., Di Stefano, A., and Marino, M. (Eds.), 2017, Field Trip Guide of . IGCP 610 and INQUA IFG POCAS Joint Plenary Conference and Field Trip, 2017, Palermo, 258 p.

Chepalyga, A.L., 2018, Chronostratigraphical correlation of Ponto-Caspian and Mediterranean basins for the reconstruction of water exchange and the first peopling of Europe. Proceedings of IGCP 610 and INQUA IFG POCAS Joint Plenary Conference and Field Trip, 2018, Antalya, pp. 46-49.

Esin, N.V., Esin, N.I., Yanko-Hombach, V., 2015, The Black Sea basin filling by the Mediterranean salt water during the Holocene. Quaternary International, v. 409 (Part A), pp. 33-38.

Esin, N.V., Yanko-Hombach, V., and Esin, N.I., 2018, Evolutionary mechanisms of the Paratethys Sea and its separation into the Black Sea and Caspian Sea. Quaternary International, v. 465 (Part A), pp. 46-53.

Frumkin, A., Langford, B., Marder, O., and Ullman, M., 2018, Quaternary development of southern Levant caves: window to Out of Africa hominin migration. Proceedings of IGCP 610 and INQUA IFG POCAS Joint Plenary Conference and Field Trip, 2018, Antalya, pp. 54-57.

Gamkrelidze, I., Okrostsvaridze, A., and Gagnidze, N., 2016, Field Trip
Guide of IGCP 610 Fourth Plenary Conference and Field of IGCP 610, 2016, Tbilisi, 19 p.

Gilbert, A. and Yanko-Hombach, V. (Eds.), 2018, Proceedings of IGCP 610 and INQUA IFG POCAS Joint Plenary Conference and Field Trip, 2018, Antalya, 203 p.

Gilbert, A., and Yanko-Hombach, V. (Eds.), 2013, Proceedings of IGCP 610 First Plenary Conference and Field Trip, 2013, Tbilisi, 182 p.

Gilbert, A., and Yanko-Hombach, V. (Eds.), 2016, Proceedings of IGCP 610 Fourth Plenary Meeting and Field Trip, 2016, Tbilisi, 218 p.

Gilbert, A., and Yanko-Hombach, V. (Eds.), 2017, Proceedings of IGCP 610 and INQUA IFG POCAS Joint Plenary Conference and Field Trip, Palermo, $258 \mathrm{p}$.

Gilbert, A., Yanko-Hombach, V., and Yanina, T. (Eds.), 2015, Proceedings of IGCP 610 Third Plenary Conference and Field Trip, 2015, Astrakhan, $220 \mathrm{p}$.

Gilbert, A., Yanko-Hombach, V. (Eds.), 2014, Proceedings of IGCP 610 Second Plenary Conference and Field Trip, 2014, Baku, 186 p.

Kadurin, S., Yanko-Hombach, V., and Smyntyna, O., 2019, Ukraine: In search of submerged late Palaeolitic sites on the north-western Black Sea shelf. In: Bailey. G., Galanidou, N., Joens, H, Lueth, F., and Peeters, H. (Eds), The Archaeology of Europe's Submerged Landscapes. Springer, Cham.

Koral, H., 2018, Field Trip Guide of IGCP 610 and INQUA IFG POCAS Joint Plenary Conference and Field Trip, 2018, Antalya, 28 p.

Mudie, P.J., Richards, K., Rochon, A., and Bakrač, K., 2018, Dinoflagellate marker species of the relic Paratethyan Seas: Pannonian to Caspian basins. Proceedings of IGCP 610 and INQUA IFG POCAS Joint Plenary Conference and Field Trip, 2018, Antalya, pp. 116-119.

Okrostsvaridze, A., Janelidze, Z., and Tushabramishvili, N., 2013, Field Trip Guide of the IGCP 610 First Plenary Conference and Field of IGCP 610, 2014, Tbilisi, 16 p.

Öniz, H., and Dönmez, G., 2018, Known examples of submerged archaeological sites from Turkey. Proceedings of IGCP 610 and INQUA IFG POCAS Joint Plenary Conference and Field Trip, 2018, Antalya, pp. 131-132.

Popov, S.V., Golovina, L.A., and Goncharova, I.A., 2018, Eastern Paratethys - Mediterranean connections during the Neogene and Quaternary. Proceedings of IGCP 610 and INQUA IFG POCAS Joint Plenary Conference and Field Trip, 2018, Antalya, pp. 140-145.

Smyntyna, O., 2007, Late Mesolithic of the Ukrainian part of the Lower Danube region: New perspectives of human adaptation and interpretation of natural environments. Quaternary International, v. 167-168, pp. $114-120$. 
Smyntyna, O.V., 2017, Adjustment theory in the study of human responses to global climate change in the Northwestern Black Sea region at the Pleistocene-Holocene boundary. Proceedings of IGCP 610 and INQUA IFG POCAS Joint Plenary Conference and Field Trip, 2017, Palermo, pp. $185-187$.

Stanko, V. N., 2007, Fluctuations in the level of the Black Sea and Mesolithic settlement of the northern Pontic area. In Yanko-Hombach, V., Gilbert, A. S., Panin, N. \& Dolukhanov, P. M. (eds.) The Black Sea Flood Question: Changes in Coastline, Climate and Human Settlement. pp. 371-386. Springer: Dordrecht.

Yanina, T., Sorokin, V., Bezrodnykh, Yu., and Romanyuk, B., 2018, Late Pleistocene climatic events reflected in the Caspian Sea geological history (based on drilling data). Quaternary International, v. 465(A), pp. 130-141.

Yanina, T., Svitoch, A., Kurbanov, R., Vasiliev, D., and Pigarev, E. 2015. Field Trip Guide of IGCP 610 Third Plenary Conference and Field Trip, 2015, Astrakhan, 44 p.

Yanina, T.A., 2012, Correlation of the Late Pleistocene paleogeographical events of the Caspian Sea and Russian Plain. Quaternary International, v. 271, pp. 120-129.

Yanina, T.A., Svitoch, A.A., Kurbanov, R.N., Murray, A.S.,Tkach, N.T., and Sychev, N.V., 2017, Experience of dating of the Pleistocene deposits of the Lower Volga area using the optically stimulated luminescence. Vestnik Moskovskogo Universiteta, Seriya 5, Geographiya, no 1, pp. 21-29 (in Russian).

Yanko-Hombach, V., Mudie P. J., Kadurin S., and Larchenkov, E., 2014, Holocene marine transgression in the Black Sea: New evidence from the northwestern Black Sea shelf. Quaternary International, v. 345, pp. 100-118.

Yanko V.V., and Motnenko I., 2012, Reconstructions of Pleistocene water intrusions from the Mediterranean and Caspian seas into the Black Sea based on Foraminifera. Materials of the XV All Russian Micropaleontological Conference: Recent Microplaeontology, Gelendzhik, pp. 186-188 (in Russian)

Yanko-Hombach, V., 2007, Controversy over Noah's Flood in the Black Sea: geological and foraminiferal evidence from the shelf. In YankoHombach, V., Gilbert, A.S., Panin, N., Dolukhanov, P.M. (Eds.), The Black Sea Flood Question: Changes in Coastline, Climate and Human Settlement, Springer, Dordrecht, pp.149-203.

Yanko-Hombach, V., 2016, Editorial to IGCP 610 Special Volume of Quaternary International 409, pp. 1-7.

Yanko-Hombach, V., 2018, The Ponto-Caspian biostratigraphy, sea level, and salinity reconstructions using benthic foraminifera as the main tool. IGCP 610 and INQUA IFG POCAS Joint Plenary Conference and Field Trip, 2018, Antalya, pp. 185-190.

Yanko-Hombach, V., Yanina, T., and Kurbanov, R., 2018, INQUA IFG 1709F Ponto-Caspian Stratigraphy and Geochronology (POCAS). Quaternary Perspectives, Issue 25, no 1, pp. 11-12.

Yanko-Hombach, V., and Kislov, A., 2018, Late Pleistocene e Holocene sea-level dynamics in the Caspian and Black Seas: Data synthesis and Paradoxical interpretations. Quaternary International, v. 465 (Part A), pp. 63-71.
Yanko-Hombach, V., Mudie P., and Gilbert A.S., 2011, Was the Black Sea catastrophically flooded during the post-glacial? Geological evidence and archaeological impacts. In: J. Benjamin, C. Bonsall, Dr. C. Pickard, and A. Fischer (Eds.), Underwater Archaeology and the Submerged Prehistory of Europe. Oxbow Books, pp. 245-262.

Yanko-Hombach, V., 2018, The Ponto-Caspian biostratigraphy, sea level, and salinity reconstructions using benthic foraminifera as the main tool. Proceedings of IGCP 610 and INQUA IFG POCAS Joint Plenary Conference and Field Trip, 2018, Antalya, pp. 185-190.

Yanko, V. 1990. Stratigraphy and palaeogeography of marine Pleistocene and Holocene deposits of the southern seas of the USSR. Mem.Soc. Geol. Ital., v.44, pp. 167-187.

Yanko, V.V., Frolov, V.T., Motnenko, I.V. 1990. Foraminifery i litologiya stratotipicheskogo gorizonta antropogena Kerchenskogo poluostrova [Foraminifera and a lithology of the stratotipic horizon an Anthropogene of the Kerch Peninsula]. Bull. MOIP. Dep. Geol. v.65 pp. 85-97 (in Russian).

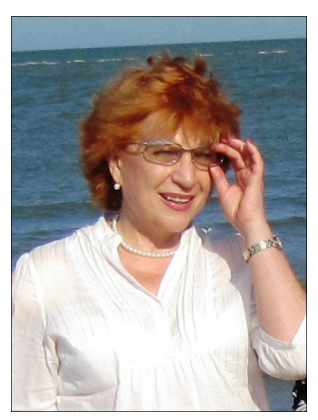

Valentina Yanko-Hombach is Doctor of Geological \& Mineralogical Sciences, Professor, Head of the Department of Physical \& Marine Geology, Director of the Scientific \& Educational Center of Geoarchaeology, Marine and Ecological Geology, Odessa I.I. Mechnikov National University (ONU), Ukraine; President of the Avalon Institute of Applied Sciences, Canada. Graduated from $\mathrm{ONU}, \mathrm{PhD}$ from ONU (1975), Dr. Sc. (venia legendi) from M.V. Lomonosov Moscow State University (1990). Research interests: micropaleontology (foraminifera), marine geology, paleooceanography, paleecology, geoarchaeology. Author/co-author of about 350 publications including 11 monographs. Leader of numerous research projects, including UNESCO, IGCP, INQUA, NATO, EU, MON of Ukraine. Has a number of scientific awards.

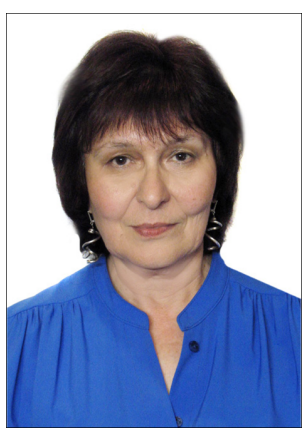

Tamara Yanina is Doctor of Geographical Sciences, Professor of the Department of Geomorphology and Paleogeography, Head of the Research Laboratory of Pleistocene Paleogeography, M.V. Lomonosov Moscow State University (MGU), Russia. Graduated from MGU (1980), PhD from MGU (1980), Dr. Sc. (venia legendi) from MGU (2009). Research interests: malacology, biostratigraphy and paleogeography of the Ponto-Caspian and surrounding areas. Author or co-author of more than 300 publications (including 25 monographs). Leader of numerous research projects funded by the Russian Science Foundation. for Basic Research, Russian Geographical Society, IGCP, INQUA. Has a number of scientific awards. 